\title{
SYSTEMATIC SIGNIFICANCE OF THE LEAF CUTICLE OF HYPODAPHNIS ZENKERI (ENGL.) STAPF (LAURACEAE) AND A RECORD OF ITS VOLATILE ORGANIC COMPOUNDS
}

\author{
A. B. Kadiri ${ }^{1 *}$, T. O. Asekun ${ }^{2}$ and J. D. Olowokudejo ${ }^{1}$ \\ ${ }^{1}$ Department of Botany, University of Lagos, Akoka Yaba Lagos, Nigeria \\ *E-mails: abkadiri2001@yahoo.com; taiwoaseku@yahoo.com \\ ${ }^{2}$ Department of Chemistry, University of Lagos, Akoka Yaba Lagos, Nigeria \\ E-mail: deledjo@yahoo.com
}

(Received 20 October, 2017; Accepted 26 June, 2018)

\begin{abstract}
Hypodaphnis zenkeri is a monotypic taxon whose position is basal in the phylogenetic tree of the family Lauraceae. Cuticular information on the plant is lacking. Given the systematic relevance of this character in the family and absence of its record for the species, the leaves of the species were investigated with the aid of light and scanning electron microscopy. Also, volatile organic compounds in leaves and fruits were studied with Gas Chromatography-Mass Spectrometry (GC-MS), for the first time. Taxonomically useful cuticular features of the species include long stomatal rim and aperture, granulated periclinal walls on the adaxial surface and superficial stomatal orientation. The leaves and fruits of the plant are rich in volatile organic compounds such as 1,2-benzene-dicarboxylic acid, hexadecanoic acid ester and stigmasta-3,5-diene. Based on these features, the species can be distinguished from other related taxa in the family.
\end{abstract}

Key words: chemistry, epidermis, microscopy, stomata

\section{INTRODUCTION}

Rate of loss of biodiversity is one great challenge in the tropical Africa caused as a result of over dependence on forest resources and other anthropogenic reasons such as industrialisation and urbanisation. By these means, many important plant species, which are poorly represented, monotypic, taxonomically difficult or restricted in distribution are worse hit. Hypodaphnis zenkeri (Engl.) Stapf is one of those plants. This species is a shrub or tree with densely leafy branches. Its leaves are thinly coriaceous, flowers are dioecious with anthers comprising four collateral valves and the ovary is inferior (Hutchinson and Dalziel 1958, Stapf 1909). It is traditionally useful in food and medicine in all its areas of occurrence (Burkhill 1985, Moukette et al. 2014).

The species is the only taxon in the genus Hypodaphnis, which has several features in common with many genera of the family Lauraceae (Chanderbali et al. 2001). The species forms the most basal taxon in the phylogenetic tree of the family Lauraceae (Chanderbali et al. 2001, Rohwer 2000, Rohwer and Richter 1987, Rohwer and Rudolph 2005). 
On the species, there exists useful information on its exo-morphology (Hutchinson and Dalziel 1958, Kostermans 1957, Rohwer 1993, Stapf 1909); and wood structure (Richter 1981); but there is lack of information on cuticular data. The leaf cuticles are an important character, which has been found taxonomically useful to the taxonomy of Lauraceae (Ceoline et al. 2009, Christophel and Rowett 1996, Christophel et al. 1996, Gomes-Bezerra et al. 2011, Kamel and Loutfy 2001, Nishida and Christophel 1999, Nishida and van der Werff 2007, 2011, 2014, Yang et al. 2012, Zeng et al. 2014), but knowledge of this feature is not complete yet on the family.

Similarly, only non-volatile chemical information about the species has been reported in the stem bark and leaves of the Hypodaphnis zenkeri (Momo et al. 2013, Moukette et al. 2014). Therefore, this study aims to document the cuticular characters of the plant which hitherto is lacking and provide additional chemical characters that partly underlie the medicinal usefulness of the plant.

\section{MATERIALS AND METHODS}

The plant is not richly distributed hence only the two preserved specimens deposited in the herbarium were consulted and used for the study. Herbarium specimens were chosen for the study because of the ease of study of the focused characters (Davis and Heywood 1963, Hillig and Mahlberg 2004, Jenkins and Patterson 1973). Leaf samples from the Forestry Herbarium Ibadan (FHI) and University of Ibadan (UIH), Nigeria were examined. The herbarium abbreviations follow Holmgren et al. (1990). Details of the specimens investigated are listed thus: Collector: J. Lowe. Herbarium: UIH 1042. Date: 12th March, 1964. Locality: Benin, Nigeria. Collector: Ariwaodo and Adesina. Herbarium: FHI 97161. Date: 29th December, 1981. Locality: Nigeria.

For cuticular study, the usual method of working for recovery of cuticular data in Lauraceae was employed. Both light and scanning electron micrographs of the leaf surfaces were obtained from one of the cross examined five leaf samples for stomatal and non-stomatal epidermal cells characters. Only the epidermal cells encountered were counted per square millimetre, while 20 randomly selected cells and stomata were measured per sample.

The leaf cuticle was studied following the approach of Nishida and van der Werff (2007). In this study, we follow the concept of Christophel and Rowett (1996) that although the plant cuticle is an inert, extra-cellular secretion of the epidermis but, the features being described are actually those of the epidermal cells and the stomatal complex whose impression is preserved in the cuticle (Fig. 1, I-III). For light microscopy (LM), the acid soaking method and counter-staining, which has proven useful proven useful for obtaining leaf cuticles from many African plants was adopted, according to the approaches of Ogundipe and Kadiri (2012), Olowokudejo (1993), Kadiri and Olowokudejo 
$(2008,2016)$ with some modifications. Leaf portions of $2-3 \mathrm{~cm}^{2}$ were cut from the standard median portion of the leaf lamina near the mid-rib, boiled in water for 30 minutes and then soaked in concentrated nitric acid $\left(\mathrm{HNO}_{3}\right)$ in capped specimen bottles for two to four hours to macerate the mesophyll tissue. Tissue disintegration was indicated by air bubbles, the stage at which the leaf tissues were transferred into Petri dishes containing water for separation of the epidermis using a pair of forceps and mounting needle. Tissue debris was cleared off the epidermis with an artist's fine-hair brush and washed in several changes of water. Two to three drops of sodium hypochlorite solu-

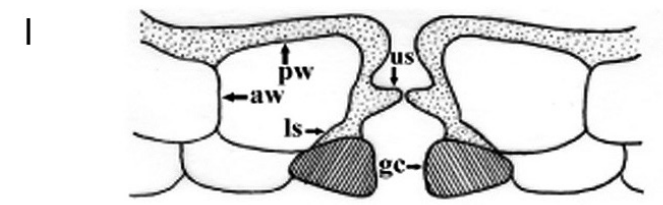

II

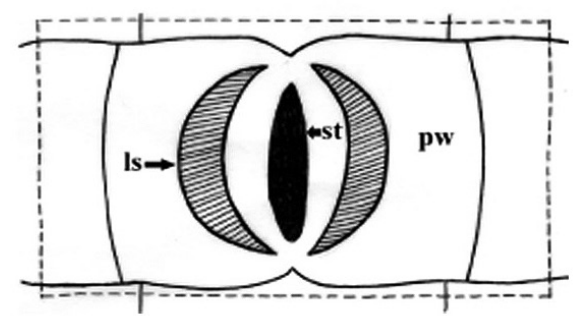

III
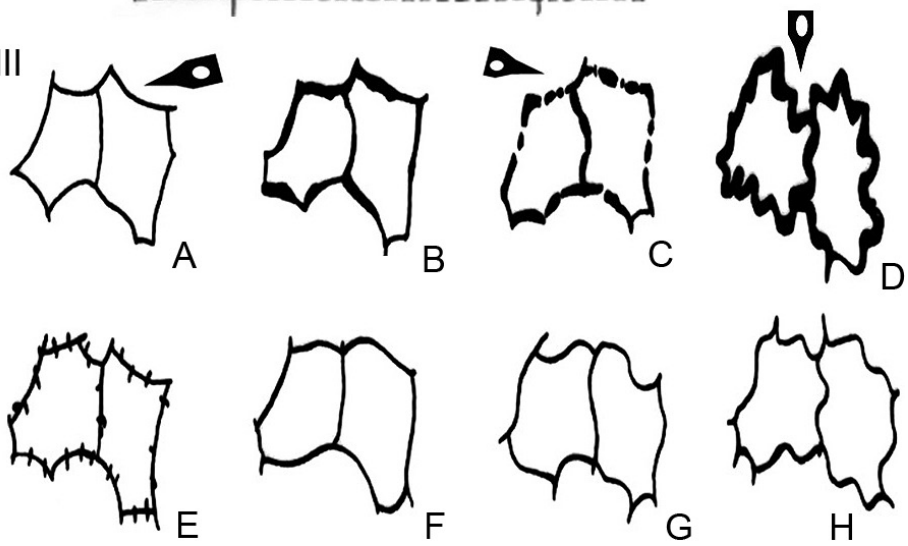

Fig. 1. Diagrams of leaf epidermis in Lauraceae. (I) Transverse section (upper) of typical Lauraceae lower epidermis; (II) lower surface of typical Lauraceae leaf cuticle. aw = anticlinal walls of epidermis; $\mathrm{gc}=$ guard cell; $1 \mathrm{~s}=$ lower stomatal ledge; $\mathrm{pw}=$ periclinal walls of epidermis; st = stomata; us = upper stomatal ledge (modified from Christophel et al. 1996, Nishida and van der Werff 2007 and Yang et al. 2013); (III) schematic views of anticlinal walls of epidermal cells. $\mathrm{A}=$ smooth and angular; $\mathrm{B}=$ irregularly thickened; $\mathrm{C}=$ beaded; $\mathrm{D}=$ buttressed; $\mathrm{E}=$ branched; $\mathrm{F}$ = rounded; $\mathrm{G}=$ undulate; $\mathrm{H}=$ sinuous (modified from Nishida and Christophel 1999). Arrows show features found in Hypodaphnis zenkeri

(Ariwaodo and Adesina, 97161, FHI) 
tion were dropped onto the epidermis on the slide to bleach opaque areas and allowed to soak for 30-120 seconds until the colour changed from bright yellow to white when washed in water. The epidermis was mounted with the outer periclinal wall upwards on the slide and then two to five drops of ethyl alcohol in a series of ascending concentrations (50\%, 75\%, and 100\%) were added to harden the cell wall. Two to three drops of $10 \%$ aqueous Methylene Blue and one drop of $50 \%$ aqueous Safranin were later added for three to five minutes. Two to three drops of glycerine were added, then the preparation was covered with a transparent cover-slip and the edges were sealed with nail polish to prevent dehydration. Each slide was observed under magnifications of $\times 100$ and $\times 400$, so as to capture all the features of the epidermis. These features were recorded qualitatively and basic statistical calculations were made to show means, standard error and ranges of variations. Photomicrographs were taken using a Zeiss Axio Imager $\mathrm{A}_{1}$ light microscope.

In addition to the light microscopic study, we examined the epidermis with a scanning electron microscope (SEM). Ca. $5 \mathrm{~mm}^{2}$ portions of the leaf lamina were obtained and dipped into $100 \%$ ethanol for 15 minutes and shaken vigorously, dried, and then fixed adaxially and abaxially on the stubs that were coated with gold. The surfaces were observed and photographed under a Hitachi s-4800 scanning electron microscope at $10.0 \mathrm{KV}$ at the State Key Laboratory of Systematic and Evolutionary Botany, Institute of Botany, the Chinese Academy of Sciences, China. Stomatal terminology is based on Metcalfe (1987), Metcalfe and Chalk (1950), Radford et al. (1976), Stace (1965) and Wilkinson (1979), and the established epidermal character descriptions for Lauraceae were adopted (Fig. 1) (Christophel et al. 1996, Nishida and Christophel 1999, Nishida and van der Werff 2007, 2011, van der Werff and Nishida 2010, Yang et al. 2012). As a general rule in the family, the nature of the two cuticular ledges, the upper part (Fig. 1: I, us) protrudes upward and sometimes outward in the stomatal pore, and arises from the lateral walls of the subsidiary cells. The lower stomatal ledges (Fig. 1, ls) protrude between the guard cells and the subsidiary cells, thus forming different shapes (Nishida and van der Werff 2007). All these features as found in Hypodaphnis were studied.

For detailed assessment of features, the LM and SEM photographs were converted to a PowerPoint document and later arranged with Adobe Photoshop CS 8.0.1.

For chemical analysis, about $1 \mathrm{~g}$ sample of leaf and fruit tissue (exocarp and mesocarp) was used. The non-polar extract of the plant was obtained by Soxhlet extraction in hexane and volatile components identified using Gas Chromatography-Mass Spectrometry (GC-MS) at the University of Lagos Central Research Laboratory, Nigeria. The chemical structures and IUPAC names of the most abundant compounds are presented in Figure 3. 
Table 1

Cuticular features of stomatal and non-stomatal cells of Hypodaphnis zenkeri under SEM

\begin{tabular}{|c|c|c|c|c|c|c|}
\hline \multicolumn{2}{|c|}{ Epidermal cell } & \multicolumn{2}{|c|}{ Stomatal rim } & \multicolumn{2}{|c|}{ Stomata orientation } & \multirow[t]{2}{*}{ Figure } \\
\hline adaxial & abaxial & adaxial & abaxial & adaxial & abaxial & \\
\hline $\begin{array}{l}\text { double } \\
\text { walled with } \\
\text { furrow }\end{array}$ & $\begin{array}{c}\text { evenly } \\
\text { thickened } \\
\text { solid walls }\end{array}$ & absent & $\begin{array}{c}\text { narrow, } \\
\text { long, smooth } \\
\text { surface }\end{array}$ & absent & superficial & $2 \mathrm{~A}-\mathrm{C}$ \\
\hline
\end{tabular}

\section{RESULTS}

\section{Cuticular study}

The general leaf cuticular character states of Lauraceae (Fig. 1) recorded in Hypodaphnis zenkeri include (i) lip-shaped lower stomatal ledge (Fig. 1: I), (ii) smooth and angular periclinal walls (Fig. 1: IIIA), (iii) beaded anticlinal walls (Fig. 1: IIIC) and (iv) buttressed anticlinal walls (Fig. 1: IIID).

Under SEM, on the abaxial surface, the anticlinal walls were evenly thickened (Fig. 2B). The stomata were oriented superficially on the epidermis, while the stomatal aperture was long and narrow like the stomatal rim (Fig. 2B). The periclinal walls have smooth surface (Fig. 2A-C, E, F; Table 1); but they can be sparsely granulated on the adaxial surface (Fig. 2D, Table 1). Epicuticular wax as plugs and flakes were also noticeable, irregularly distributed on the adaxial but sparsely occurring on the abaxial surface (Fig. 2A, B).

However, under light microscopy, anticlinal walls were straight, angular or rounded on both surfaces. Anticlinal wall thickness is buttressed on the adaxial surface (Fig. 2D, Table 2) and, beaded or not beaded on the abaxial surface (Fig. 2E; Table 2). The cells are polygonal in shape (Fig. 2D). Cell size varied from $42.0-77.0 \mu \mathrm{m}$ by $28.0-52.5 \mu \mathrm{m}$ on the adaxial surface to $52.5-105.0$ $\mu \mathrm{m}$ by $28.0-52.5 \mu \mathrm{m}$ on the abaxial surface. Stomatal pore size varied from 9.6-12.0 by $2.4-3.6 \mu \mathrm{m}$ (Table 3). Stomatal type is paracytic and the number of interstomatal epidermal cells varied from 1-3.

Table 2

Cuticular features of stomatal and non-stomatal cells of Hypodaphnis zenkeri under LM

\begin{tabular}{|c|c|c|c|c|c|c|c|}
\hline \multirow{2}{*}{\multicolumn{2}{|c|}{$\begin{array}{l}\text { Periclinal wall } \\
\text { ornamentation }\end{array}$}} & \multicolumn{4}{|c|}{ Anticlinal wall } & \multirow{3}{*}{$\begin{array}{l}\text { Lower sto- } \\
\text { matal ledge } \\
\text { shape }\end{array}$} & \multirow[t]{3}{*}{ Fig. } \\
\hline & & \multicolumn{2}{|c|}{ straightness } & \multicolumn{2}{|c|}{ thickness uniformity } & & \\
\hline adaxial & abaxial & adaxial & abaxial & adaxial & abaxial & & \\
\hline $\begin{array}{c}\text { smooth, sparse- } \\
\text { ly granulated }\end{array}$ & smooth & $\begin{array}{l}\text { S/A to } \\
\text { round }\end{array}$ & $\begin{array}{l}\text { S/A to } \\
\text { round }\end{array}$ & $\begin{array}{l}\text { but- } \\
\text { tressed }\end{array}$ & $\begin{array}{l}\text { beaded / } \\
\text { not beaded }\end{array}$ & lip-shaped & $\begin{array}{c}\text { 2D, } \\
\mathrm{E}\end{array}$ \\
\hline
\end{tabular}


Phytochemical study

Some volatile organic compounds grouped into fatty acid methyl esters and phthalates were found in the fruit and leave extracts (Table 4). The chemi-
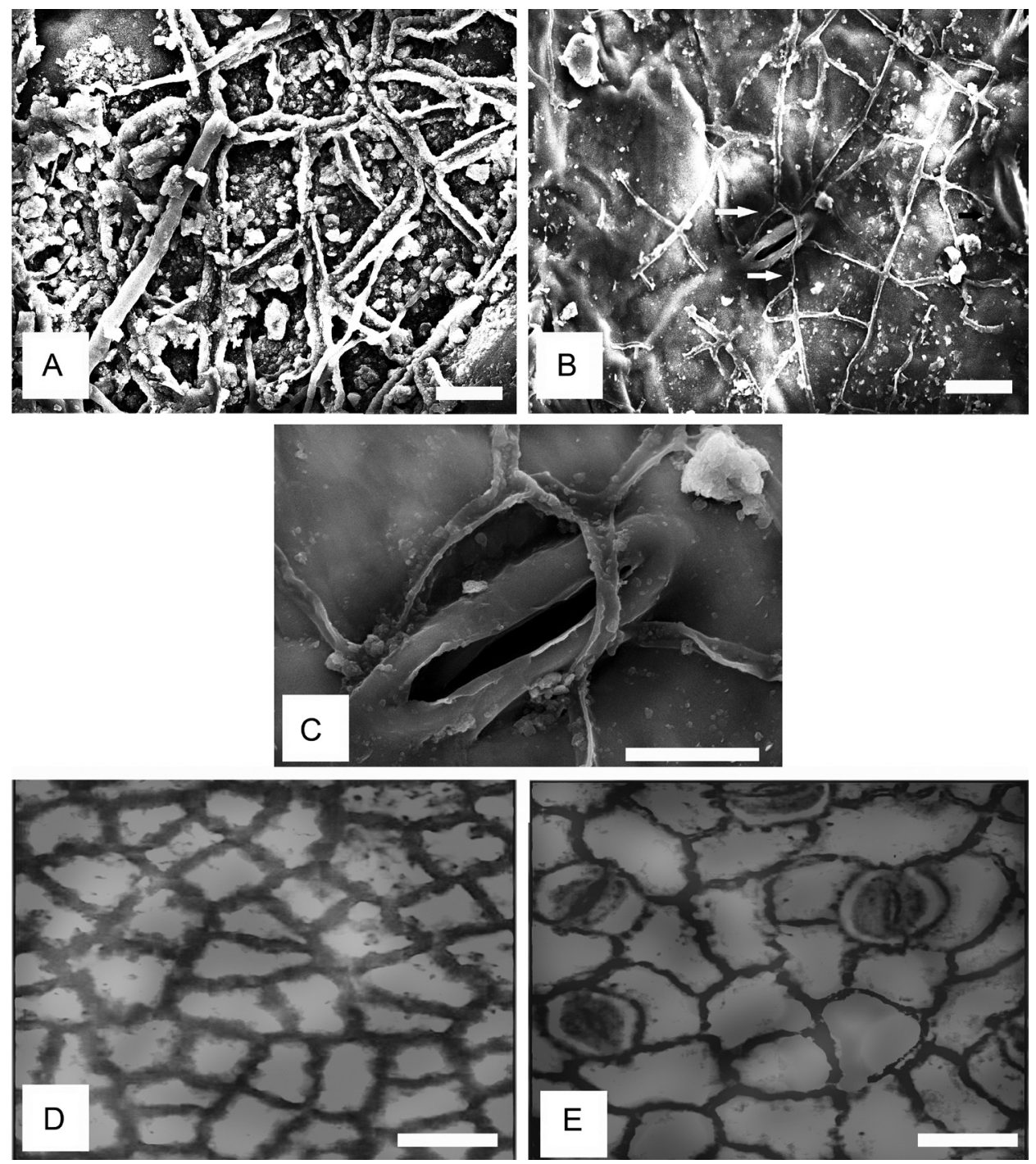

Fig. 2. Leaf cuticular features of Hypodaphnis zenkeri (Ariwaodo and Adesina, 97161, FHI). A-C: SEM micrographs. A = double walled periclinal walls and epicuticular wax flakes; B = sunken stomata (arrowed); $\mathrm{C}=\mathrm{a}$ stoma at a higher magnification revealing long stomatal lips; D-E: LM micrographs. D = (adaxial epidermis), thick walled polygonal cells and granulated periclinal walls; $\mathrm{E}=$ (abaxial epidermis), depicts beaded and un-beaded anticlinal walls, and paracytic stomata type. Scale bars: A, B $=5 \mu \mathrm{m} ; \mathrm{C}=10 \mu \mathrm{m} ; \mathrm{D}, \mathrm{E}=35 \mu \mathrm{m}$ 
Table 3

Quantitative stomatal and non-stomatal features of Hypodaphnis zenkeri

\begin{tabular}{cccccccc}
\hline \multicolumn{2}{c}{ Stomata } & \multicolumn{3}{c}{ Epidermal cells } \\
\hline \multicolumn{2}{c}{ number per $\mathrm{mm}^{2}$} & \multicolumn{2}{c}{ number per $\mathrm{mm}^{2}$} & \multicolumn{2}{c}{ length $(\mu \mathrm{m})^{*}$} & \multicolumn{2}{c}{ width $(\mu \mathrm{m})^{*}$} \\
\hline adaxial & abaxial & adaxial & abaxial & adaxial & abaxial & adaxial & abaxial \\
- & 49 & 428 & 279 & $42.0-77.0$ & $52.5-105.0$ & $28.0-52.5$ & $28.0-63.0$ \\
\hline
\end{tabular}

*Size is expressed as minimum value to maximum value

Table 4

Volatile organic compounds in the leaf and fruit of Hypodaphnis zenkeri

\begin{tabular}{lcc}
\hline Compound & Leaf & Fruit \\
\hline Methyl ester & $\begin{array}{c}\text { present as hexadeca- } \\
\text { noic acid methyl ester }\end{array}$ & $\begin{array}{c}\text { present as octadecanoic } \\
\text { acid methyl ester }\end{array}$ \\
Bis(2-ethylbutyl ester) phthalate & present & present \\
\hline
\end{tabular}

S/A: Straight and angular

cal structures of the most abundant compounds are shown in Figure 3. Three volatile compounds, hexadecanoic acid, methyl ester (48.10\%), 11-octadecanoic acid, methyl ester (20.82\%) and diisooctyl phthalate and dioctyl phthalate $(31.18 \%)$ were found in the leaf extract. Other prominent volatile characters in the fruit extract included dibutyl phthalate $(8.30 \%)$, cyclooctacosane $(8.17 \%)$, pentadecane, 2,6,10,14-tetramethyl ester (6.31\%) and hexadecanoic acid, methyl ester (5.40\%). The chemical structures of the representative compounds are shown in Figure 3A-C.<smiles>CCC(CC)COC(=O)c1ccccc1C(=O)OCC(CC)CC</smiles>

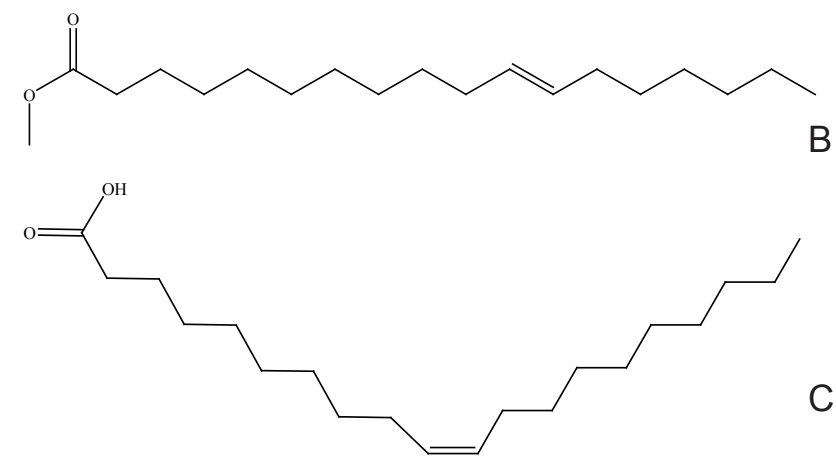

Fig. 3. Chemical structures of abundant volatile chemicals in the leaf and fruit of Hypodaphnis zenkeri (Ariwaodo and Adesina, 97161, FHI). A =1,2 benzene dicarboxylic acid (bis 2-ethylbutyl ester); $\mathrm{B}=11$-octadecanoic acid (methyl ester); $\mathrm{C}=9$-octadecanoic acid (methyl ester) 


\section{DISCUSSION}

Some taxonomically useful features obtained from leaf epidermal morphology and chemistry of Hypodaphnis zenkeri are reported. This has updated our knowledge of the cuticular data in Lauraceae, while the chemical characters are added to the lists of chemicals found in the family. Cuticular information is exceptionally useful for understanding affinities and relationships among taxa in the family Lauraceae (Christophel et al. 1996, Nishida and van der Werff 2014, Nishida et al. 2016, Yang et al. 2012). The leaf cuticular characters of $H$. zenkeri are within the generalised cuticular data already documented for the Lauraceae family (Fig. 1). The general features shared include hypostomatic leaf and paracytic stomata. Other features, which had been reported in other genera but also found in $H$. zenkeri, include lip-shaped lower stomatal ledges (Fig. 1, I), straightness of anticlinal walls, which is straight, angular to rounded as found in the Beilschmiedia group, e.g. Beilschmiedia, Potameia Thouars and Endiandra R. Br. (Yang et al. 2012) and Cryptocarya spp. e.g. Cryptocarya Brown. H. zenkeri can still be further differentiated from Beilschmiedia spp. based on quantitative cuticular data. Nishida and Christophel (1999) reported cell dimension of $20-60 \mu \mathrm{m}$ on the adaxial surface and $20-40 \mu \mathrm{m}$ on the abaxial surface among the Neotropical species of Beilschmiedia; the values obtained on the African representatives are also within the ranges (Kadiri et al. under review); but these values varied from $42.0-77.0 \mu \mathrm{m}$ on the adaxial surface to 52.5-105.0 $\mu \mathrm{m}$ on the abaxial surface in Hypodaphnis.

At the generic level, based on the molecular data of Chanderbali et al. (2001), H. zenkeri is sister to the Cryprocarya species. Epicuticular wax has been correlated with granulated periclinal walls (Nishida et al. 2016). Granulated periclinal walls were absent in the Beilschmiedia spp., but they were present on the adaxial surface of $H$. zenkeri and on the abaxial surface of Cryptocarya spp. (Nishida et al. 2016). Comparison of cuticular features of the species of the genera Beilschmiedia, Cryptocarya and Hypodaphnis is suggested for a future work.

The existing molecular studies support placement of Hypodaphnis as a genus in Lauraceae (Chanderbali et al. 2001, Renner and Chanderbali 2000, Rohwer 2000, Rohwer and Rudolph 2005); this is also strongly supported here given the suite of cuticular data found in the species.

Inclusion of chemical data in the present study is basically to provide information on the chemical basis of the aromatic nature of the plant. The various chemicals found with Gas Chromatography-Mass Spectrometry (GC-MS) in the leaves and fruits of the plant are all volatile. Mahmoodi Sourestani et al. (2014) reported that medicinal and aromatic plants (MAPs) are often stored for long periods before use, in order to manufacture various types of products. Phytochemical constituents can be affected (Asekun et al. 2007, Capecka 
et al. 2005, Orav 2004, Stafford et al. 2005) or there may be no significant differences in essential oils (volatile compounds) content of certain plants after a period of storage and even geographical locations (Ebadi et al. 2017, Hillig and Mahlberg 2004, Jenkins and Patterson 1973, Rosado et al. 2013). A followup work on differential variation of chemical constituents of dry (stored) and fresh leaves of Hypodaphnis zenkeri is desirable in the future.

The abundance of dioctyl phthalates in the plant is noteworthy. When the compound is added to plastics, it allows the long polyvinyl molecules to slide against one another (Carlstedt et al. 2013). It has a clear syrupy liquid consistency and show low water solubility, high oil solubility, and low volatility (Carlstedt et al. 2013, Heudorf et al. 2007, Wilson 1995, Wypych 2004). The phthalates are however known to be contaminants (Carlstedt et al. 2013, Heudorf et al. 2007). Hexadecanoic acid ester also called palmitic acid ester is an emollient, perfuming agent and a skin conditioning agent. Hitherto, certain antioxidants, polyphenol, flavonoids, caffeic acid, $\mathrm{OH}$-tyrosol acid, and rutin isolated with high performance liquid chromatography (HPLC) have been reported also in the leaves and stem bark of the plant (Momo et al. 2013, Moukette et al. 2014). Other healthy organic free fatty acid like oleic acid, which is an important component of human diet is also identified in the plant. Stigmasta-3,5-diene, which occurred in minute amount in the fruit is a compound used for ascertaining the authenticity of olive oil (Amelio et al. 1998, Aued-Pimentel et al. 2013). With these characters of the leaf cuticles as well as fruit and leaf chemicals, it appears H. zenkeri can be distinguished from other related species in the family.

\section{CONCLUSION}

The cuticular data of the leaves reported are in line with the existing information about the family Lauraceae. The taxonomically useful cuticular features include long stomatal rim, granulated periclinal walls on the adaxial surface and superficial stomatal orientation. The volatile compounds found in the fruits and leaves of the plant may also be helpful in distinguishing the species from other related taxa. This report is the first account of leaf cuticular data and volatile organic compounds in Hypodaphnis zenkeri.

\section{REFERENCES}

Amelio, M., Rizzo, R. and Varazini, F. (1998): Separation of stigmasta-3, 5-diene, squalene isomers, and wax esters from olive oils by single high-performance liquid chromatography run. - J. Amer. Oil Chem. Soc. 75(4): 527-530. https://doi.org/10.1007/s11746998-0259-5 
Asekun, O. T., Grierson, D. S. and Afolayan, A. J. (2007): Effects of drying methods on the quality and quantity of the essential oil of Mentha longifolia L. subsp. capensis. Food Chem. 101(3): 995-998. https://doi.org/10.1016/j.foodchem.2006.02.052

Aued-Pimentel, S., Silva, S. A. D., Takemoto, E. and Cano, C. B. (2013): Stigmastadiene and specific extinction $(270 \mathrm{~nm})$ to evaluate the presence of refined oils in virgin olive oil commercialized in Brazil. - Food Sci. Technol. 33(3): 479-484. https://doi.org/10.1590/ s0101-20612013005000067

Burkhill, H. M. (1985): Useful plants of west tropical Africa. - Royal Botanic Gardens, Kew.

Capecka, E., Mareczek, A. and Leja, M. (2005): Antioxidant activity of fresh and dry herbs of some Lamiaceae species. - Food chemistry 93(2): 223-226. https://doi.org/10.1016/j. foodchem.2004.09.020

Carlstedt, F., Jönsson, B. A. G. and Bornehag, C. G. (2013): PVC flooring is related to human uptake of phthalates in infants. - Indoor Air 23(1): 32-39. https://doi.org/10.1111/ j.1600-0668.2012.00788.x

Ceoline, G. B., Rosito, J. M. and do Canto-Dorow, T. S. (2009): Leaf surface characters applied to Lauraceae taxonomy in a seasonal forest of Southern Brazil. - Brazilian Arch. Biol. Technol. 52(6): 1453-1460. https://doi.org/10.1590/s1516-89132009000600017

Chanderbali, A. S., van der Werff, H. and Renner, S. S. (2001): Phylogeny and historical biogeography of Lauraceae: evidence from the chloroplast and nuclear genomes. - Ann. Missouri Bot. Gard. 88: 104-134. https://doi.org/10.2307/2666133

Christophel, D. C. and Rowett, A. I. (1996): Leaf and cuticle atlas of Australian leafy Lauraceae. - Australian Biological Resources Study, Canberra, 217 pp.

Christophel, D. C., Kerrigan, R. and Rowett, A. I. (1996): The use of cuticular features in the taxonomy of the Lauraceae. - Ann. Missouri Bot. Gard. 83: 419-432. https://doi. org/10.2307/2399871

Davis, P. H. and Heywood, V. H. (1963): Principles of angiosperm taxonomy. - Oliver \& Boyd. Ltd., Edinburgh, 556 pp.

Ebadi, M.-T., Sefidkon, F., Azizi, M. and Ahmadi, N. (2017): Packaging methods and storage duration affect essential oil content and composition of lemon verbena (Lippia citriodora Kunth.). - Food Sci. Nutrit. 5(3): 588-595. https://doi.org/10.1002/fsn3.434

Gomes-Bezerra, K. M., Soares-Silva, L. H. and Gomes, S. M. (2011): Arquitectura foliar de las Lauraceae del Distrito Federal, Brasil, y nuevos patrones de venación propuestos. - Gayana Bot. 68(1): 1-15. https://doi.org/10.4067/s0717-66432011000100001

Heudorf, U., Mersch-Sundermann, V. and Angerer, J. (2007): Phthalates: toxicology and exposure. - Int. J. Hygiene Environm. Health 210(5): 623-634.

Hillig, K. W. and Mahlberg, P. G. (2004): A chemotaxonomic analysis of cannabinoid variation in Cannabis (Cannabaceae). - Amer. J. Bot. 91(6): 966-975. https://doi.org/10.3732/ ajb.91.6.966

Holmgren, P. K., Keuken, W. and Schofield, E. K. (1990): Index Herbariorum, Part 1: the herbaria of the world. 7th ed. - Regnum Vegetabile 106: 1-456.

Hutchinson, J. and Dalziel, J. M. (1958): Flora of west tropical Africa. - White Friars Press Ltd, London, 700 pp.

Jenkins, R. W. and Patterson, D. A. (1973): The relationship between chemical composition and geographical origin of Cannabis. - Forensic Sci. 2: 59-66. https://doi. org/10.1016/0300-9432(73)90014-9

Kadiri, A. B. and Olowokudejo, J. D. (2008): Comparative foliar epidermal morphology of the West African species of the genus Afzelia Smith (Leguminosae, Caesalpinioideae). - Gayana Bot. 65(1): 84-92. https://doi.org/10.4067/s0717-66432008000100008 
Kadiri, A. B. and Olowokudejo, J. D. (2016): Systematic significance of foliar epidermis and tendril morphology in three West African genera of Cucurbitaceae: Momordica L., Luffa Mill. and Trichosanthes L. - Webbia 71(1): 91-105. https://doi.org/10.1080/0083 7792.2015.1108683

Kamel, E. A. and Loutfy, M. H. A. (2001): The significance of cuticular features, petiole anatomy and SDS-PAGE in the taxonomy of Lauraceae. - Pakistan J. Biol. Sci. 4(9): 1094-1100. https://doi.org/10.3923/pjbs.2001.1094.1100

Kostermans, A. J. G. H. (1957): Lauraceae. - Comm. Forest Res. Inst. 57: 1-64.

Mahmoodi Sourestani, M., Malekzadeh, M. and Tava, A. (2014): Influence of drying, storage and distillation times on essential oil yield and composition of anise hyssop (Agastache foeniculum (Pursh.) Kuntze). - J. Essential Oil Res. 26: 177-184. https:// doi.org/10.1080/10412905.2014.882274

Metcalfe, C. R. (1987): Anatomy of the dicotyledons. Vol. 3. Magnoliales, Illiciales, and Laurales (sensu Armen Takhtajan). 2nd ed. - Clarendon Press, Oxford, 224 pp.

Metcalfe, C. R. and Chalk, L. (1950): Anatomy of the dicotyledons. 2 vols. - Clarendon Press, Oxford.

Momo, I. J., Dufat, T. H., Wandji, J., Michel, S. and Chiozem, D. D. (2013): New triterpenoids from the stem bark of Hypodaphnis zenkeri. - Nat. Products Res. 27(2): 137-145. https://doi.org/10.1080/14786419.2012.662647

Moukette, B., Pieme, C. A., Biapa, P. C. N., Njimou, J. R., Moor, V. J. A., Stoller, M., Bravi, M. and Ngogang, J. Y. (2014): Phenolic content of Hypodaphnis zenkeri and its antioxidant effects against Fenton Reactions' mediated oxidative injuries on liver homogenate. - Antioxidants (Basel) 3(4): 866-889. https://doi.org/10.3390/antiox3040866

Nishida, S. and Christophel, D. C. (1999): Leaf anatomy of Beilschmiedia (Lauraceae) in the Neotropics. - Nature and Human Activities 4: 9-43.

Nishida, S. and van der Werff, H. (2007): Are cuticular characters useful in solving generic relationship of problematic species of Lauraceae? - Taxon 56: 1229-1237. https://doi. org/10.2307/25065914

Nishida, S. and van der Werff, H. (2011): An evaluation of classification by cuticular characters of the Lauraceae: a comparison to molecular phylogeny. - Ann. Missouri Bot. Gard. 98: 348-357. https://doi.org/10.3417/2010054

Nishida, S. and van der Werff, H. (2014): Do cuticle characters support the recognition of Alseodaphne, Nothaphoebe and Dehaasia as distinct genera? - Reinwardtia 14: 53-66. https://doi.org/10.14203/reinwardtia.v14i1.395

Nishida, S., de Kok, R. and Yang, Y. (2016): Cuticular features of Cryptocarya (Lauraceae) from Peninsular Malaysia, Thailand and Indo-China and its taxonomic implications. - Phytotaxa 244(1): 26-44. https://doi.org/10.11646/phytotaxa.244.1.2

Ogundipe, O. T. and Kadiri, A. B. (2012): Comparative foliar epidermal morphology of the West African species of Amaranthaceae Juss. - Feddes Repert. 123(2): 97-116. https:// doi.org/10.1002/fedr.201100003

Olowokudejo, J. D. (1993): Comparative epidermal morphology of West African species of Jatropha Linn. (Euphorbiaceae). - Bot. J. Linn. Soc. 111(2): 139-154. https://doi. org/10.1006/bojl.1993.1012

Orav, A. (2004): Effect of storage on the essential oil composition of Piper nigrum L. fruits of different ripening states. - J. Agric. Food Chem. 52: 2582-2586. https://doi.org/10.1021/ jf030635s

Radford, A. E., Dickison, W. C., Massey, J. R. and Bell, C. R. (1976): Vascular plant systematics. - Harper and Row, New York, 891 pp. 
Renner, S. and Chanderbali, A. (2000): What is the relationship among Hernandiaceae, Lauraceae and Monimiaceae, and why is this question so difficult to answer? - Int. J. Plant Sci. 161(Suppl.): S109-S119. https://doi.org/10.1086/317574

Richter, H. G. (1981): Anatomie des sekundären Xylems und der Rinde der Lauraceae. Sonderb. Naturwiss. Vereins Hamburg 5: 1-148.

Rohwer, J. G. (1993): Lauraceae. - In: Kubitzki, K., Rohwer, J. G. and Bittrich, V. (eds): The families and genera of vascular plants. Vol. 2. Dicotyledons-Magnoliid, Hamamelid and Caryophyllid families. Springer-Verlag, Berlin, pp. 366-391.

Rohwer, J. G. (2000): Towards a phylogenetic classification of the Lauraceae: evidence from matK sequences. - Syst. Bot. 25: 60-71. https://doi.org/10.2307/2666673

Rohwer, J. G. and Richter, H. G. (1987): Aspidostemon, a new lauraceous genus from Madagascar. - Bot. Jahrb. Syst., Pflanzengesch. Pflanzengeogr. 109: 71-79.

Rohwer, J. G. and Rudolph, B. (2005): Jumping genera: the phylogenetic positions of Cassytha, Hypodaphnis, and Neocinnamomum (Lauraceae) based on different analyses of trnK intron sequences. - Ann. Missouri Bot. Gard. 92: 153-178.

Rosado, L. D. S., Pinto, J. E. B. P., Bertolucci, S. K. V., Jesus, H. C. R. D. and Alves, P. B. (2013): Changes in the content and composition of the essential oil of Ocimum basilicum L. during storage. - J. Essential Oil Res. 25: 227-232.

Stace, C. A. (1965): Cuticular studies as an aid to plant taxonomy. - Bull. British Mus. (Nat. Hist.) Botany 4(1): 1-71.

Stafford, G. I., Jäger, A. K. and van Staden, J. (2005): Effect of storage on the chemical composition and biological activity of several popular South African medicinal plants. - J. Ethnopharmacol. 97(1): 107-115. https://doi.org/10.1016/j.jep.2004.10.021

Stapf, O. (1909): Order CXVI. Laurineae. - In: Thiselton-Dyer, W. T. (ed.): Flora of tropical Africa. Reeve, London, Vol. 6, pp. 171-188.

van der Werff, H. and Nishida, S. (2010): Yasunia (Lauraceae), a new genus with two species from Ecuador and Peru. - Novon 20: 493-502. https://doi.org/10.3417/2010030

Wilkinson, H. P. (1979): The plant surface (mainly leaf). - In: Metcalfe, C. R. (ed.): Anatomy of the dicotyledons. 2nd ed., Oxford University Press, New York, Vol. 1, pp. 97-165.

Wilson, A. S. (1995): Plasticisers: principles and practice. - Institute of Materials Publishing, London, $316 \mathrm{pp}$.

Wypych, G. (2004): Handbook of plasticizers. - ChemTec Publishing, Toronto, 687 pp.

Yang, Y., Zhang, L. Y., Liu, B. and van der Werff, H. (2012): Leaf cuticular anatomy and taxonomy of Syndiclis (Lauraceae) and its allies. - Syst. Bot. 37: 861-878. https://doi. org/10.1600/036364412x656518

Zeng, G., Liu, B., van der Werff, H., Ferguson, D. K. and Yang, Y. (2014): Origin and evolution of the unusual leaf epidermis of Caryodaphnopsis (Lauraceae). - Perspect. Plant Ecol., Evol. Syst. 16: 296-309. https://doi.org/10.1016/j.ppees.2014.07.003 